Área Abierta. Revista de comunicación audiovisual y publicitaria ISSN: 2530-7592 / ISSNe: 1578-8393

\title{
Los ideales culturales versus la pasión de la mujer: un análisis textual de Jane Eyre (Cary Fukunaga, 2011)
}

\author{
Tecla González Hortigüela'; Eva Parrondo Coppel²
}

Recibido: 17 de octubre de 2019 / Aceptado: 14 de enero de 2020

Resumen. La hipótesis que proponemos en este trabajo es que con la reescritura de esta novela de Charlotte Brontë (1847), la guionista Moira Buffini y el cineasta Cary Fukunaga hacen dos cosas: en primer lugar, recuperan la imbricación entre la violencia y la sexualidad que caracteriza a los relatos literarios y cinematográficos pertenecientes al género gótico femenino. Y, en segundo lugar, mediante su adaptación guionista y director actualizan dicho género, en la medida en que ahondan en la oposición estructural existente entre, por un lado, los ideales culturales -tales como la pureza femenina, o la independencia de la mujer-y, por otro lado, el apasionado deseo heterosexual de algunas mujeres.

Palabras clave: Jane Eyre; Cary Fukunaga; análisis textual; género gótico femenino; ideales culturales; sexualidad femenina; violencia

\section{[en] Cultural Ideals versus Woman's Passion: A textual analysis of Jane Eyre (Cary Fukunaga, 2011)}

\begin{abstract}
The hypothesis we put forward in this paper is that in the reworking of the novel Jane Eyre by Charlotte Brontë (1847), the film's screenwriter Moira Buffini and filmmaker Cary Fukunaga do two things: first, they recover and highlight the interweaving between violence and sexuality that characterizes literary and cinematographic stories belonging to the female Gothic genre. Secondly, through their screenwriting and directorial adaptation, they update that genre, insofar as they deepen in the structural opposition between cultural ideals on the one hand, such as female purity or women's independence and, on the other, the passionate heterosexual desire of some women.
\end{abstract}

Key words: Jane Eyre; Cary Fukunaga; textual analysis; female gothic genre; cultural ideals; female sexuality; violence

Sumario. 1. Introducción. 2. El motivo del encierro y de la fuga. 3. Los ideales culturales. 4. Sexualidad y violencia. 5. La ley del deseo versus la ley moral-religiosa. 6. Conclusiones. 7. Bibliografía.

Cómo citar. Gonzalez Hortigüela, Tecla y Parrondo Coppel, Eva (2020). Los ideales culturales versus la pasión de la mujer: un análisis textual de Jane Eyre (Cary Fukunaga, 2011). Área Abierta. Revista de comunicación audiovisual y publicitaria 20 (1), 95-121, https://dx.doi.org/10.5209/arab.66091

\footnotetext{
$1 \quad$ Universidad de Valladolid (España)

E-mail: teclagonzalez@gmail.com

2 Asociación Española de Historiadores de Cine (España)

E-mail: eparrondo@hotmail.com
} 


\section{Introducción}

En el año 2011, el cineasta Cary Joji Fukunaga realizó, a partir del guion de Moira Buffini, una adaptación cinematográfica de Jane Eyre, la extensa novela gótica que la escritora británica Charlotte Brontë publicó en 1847.

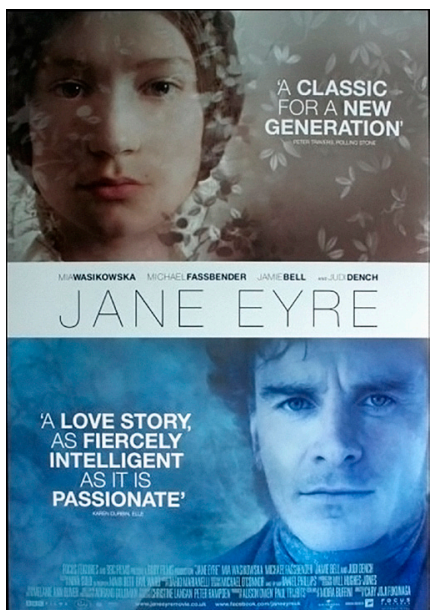

Imagen 1. "Un clásico para una nueva generación" / "Una historia de amor tan ferozmente inteligente como apasionada". Jane Eyre (Cary Fukunaga, 2011).

[Fuente: Captura de pantalla].

En el momento de la publicación de la novela, tal y como documentan en su clásico estudio Sandra M. Gilbert y Susan Gubar, Jane Eyre impresionó e indignó a los críticos y reseñistas victorianos:

Jane Eyre es la personificación completa de un espíritu impenitente e indisciplinado», escribió Elizabeth Rigby en The Quarterly Review en 1848, y su «autobiografía [...] es fundamentalmente una composición anticristiana (1979: 342).

Si bien la crítica ortodoxa del siglo XIX subraya que la publicación de Jane Eyre produjo "la más alarmante revolución" en la cultura victoriana (Oliphant, 1855, citado en Gilbert y Gubar, 1979: 343), durante el siglo XX se ha incidido, por el contrario, en el profundo carácter moralizante de la novela (Cecil, 1934; Craik, 1971; García Doncel, 1988; Perojo, 1994), así como se ha interpretado que lo central en la obra de Charlotte Brontë es la alienación de la escritora en la tradición puritana (Fernández Nistal, 1986). Desde esta perspectiva, que entiende que "en el comportamiento de la protagonista (...) no hay ni una sola transgresión importante del código de castidad victoriano" (García-Doncel, 1988: 263), se considera que la novela de Brontë supone el "triunfo del bien sobre el mal, de la virtud sobre el pecado", pecado que estaría representando "de forma innegable", según señala $\mathrm{M}^{\mathrm{a}}$ Eugenia Perojo, por la figura del Rochester-satánico, en tanto que este personaje masculino, fuerte y orgulloso, simboliza "la tiranía de la carne" (1994: 267-270).

En oposición a esta lectura de corte moralista que anula el carácter "subversivo" de la novela, una de las principales aportaciones de Gilbert y Gubar es que ponen en 
primer término que lo que "horrorizó" a los victorianos de esta novela no fue tanto el carácter carnal y demoníaco de Rochester, sino, más bien, el carácter carnal y demoníaco de la propia Jane, esto es, su "hambre, rebelión y furia" apasionada (1979: 344).

Es esta perspectiva, que establece una relación de causa-efecto entre el hecho de que Jane Eyre sea un personaje femenino díscolo y ardiente y el escándalo - $\mathrm{y}$ consecuente condena - que produjo la novela en la sociedad de la época, la que queremos retomar aquí. Deseamos proponer no solo que este relato sigue siendo a día de hoy políticamente "peligroso" (Gilbert y Gubar, 1979: 344), sino también que la re-escritura que realizan Buffini y Fukunaga supone una lectura que apuntaría a relanzar el carácter crítico y, por tanto, político de la novela de Brontë y, por extensión, del género gótico cinematográfico que, tras Rebeca (Alfred Hitchcock, 1940), floreció en Hollywood durante la década de 1940.

Como es característico en este género, Buffini y Fukunaga retoman una puesta en escena en la que se despliega la imbricación entre la pasión sexual y la violencia desde el punto de vista subjetivo de la protagonista, de un modo similar al cine negro romántico el cual, tal y como ha sido señalado por Krutnik, lo hace desde el punto de vista masculino (1991). Sin embargo, lo que nos interesa subrayar no es tanto la inserción de la película en la tradición del género gótico, sino el hecho de que, con su adaptación, guionista y cineasta aportan algo históricamente inédito (Elizabeth Cowie, en Neale, 1990: 51, 56). Al recuperar, frente al resto de las adaptaciones cinematográficas ${ }^{3}$, toda la tercera y última parte de la novela, que es la que narra con detalle la relación entre Jane Eyre y el pastor protestante John Rivers, Buffini y Fukunaga no sólo revitalizan en el filme la defensa "anticristiana" que, en el contexto victoriano, lleva a cabo Charlotte Brontë de la sexualidad de la mujer, sino que también ponen en primer plano la moderna tensión entre la pasión violenta de las mujeres y la represión puritana de la misma ejercida por los representantes de la ley moral-protestante, ley que está en el origen mismo del capitalismo (Weber, 1905).

Si en el siglo XIX, un siglo marcado por los ideales morales de "la virtud" y de "la espiritualidad pura" de las mujeres —eso que Virginia Woolf nombró como "el fantasma" del "ángel en la casa" (1992: 3) - , publicar una novela protagonizada por una joven que está habitada por una violenta pasión mantenía "una relación única con el espíritu romántico de la revuelta" (Gilbert y Gubar, 1979: 95); en el siglo XXI, lo que, a nuestro juicio, viene a mantener una relación única con el espíritu romántico de "la revuelta" - entendiendo por revuelta "una contestación de las normas, de los valores, de los poderes ya establecidos" (Kristeva, 2000: 13) - es precisamente poner en circulación un relato cinematográfico en el que la pasión desenfrenada de la protagonista se dirige hacia un hombre sexualmente experimentado y, sobre todo, ferozmente viril, al estilo del héroe byroniano tan apreciado por Charlotte Brontë y por otras novelistas góticas ${ }^{4}$.

Robert Stevenson realizó una adaptación de Jane Eyre en 1943 y Franco Zefirelli volvió a adaptar la novela de Brontë en 1996.

$4 \quad$ El término héroe byroniano define un tipo de personaje heroico que es a la vez idealizado e imperfecto, retratado por primera vez en el poema épico semi-autobigráfico de Lord Byron Las peregrinaciones de Childe Harold (1812). 


\section{El motivo del encierro y la fuga}

La película comienza in extrema res con Jane huyendo del castillo de Thornfield.
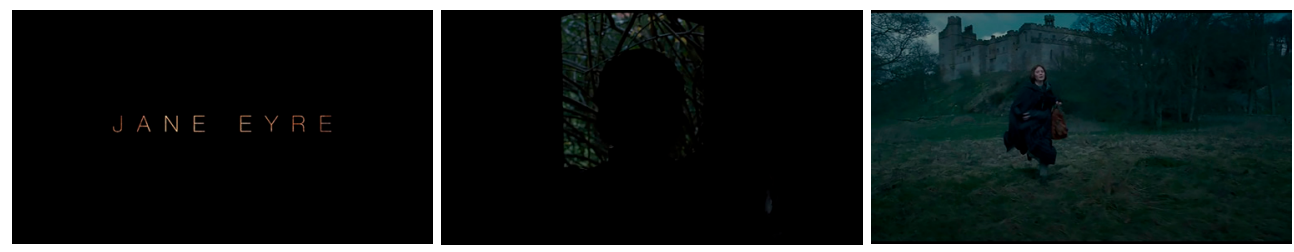

Imágenes 2,3 y $4^{5}$

[Fuente: Captura de pantalla].

Este arranque narrativo, consistente en comenzar la narración no por el principio, ni siquiera por el medio - in media res-, sino por un punto ya próximo al final —in extrema res-, implica al menos tres cosas.

La primera es que se nos anuncia que la narración va a recurrir al empleo del recurso narrativo del flashback para explicar cómo la protagonista llegó hasta este momento simbólicamente crucial en el que, con la apertura de una puerta -imagen 3 -, con la entrada de la luz que rasga el negro de la pantalla de cine, se inicia también el relato protagonizado por Jane Eyre. La película, en efecto, se estructura alrededor de cuatro flashbacks: un primer flashback en la casa de la tía Reed, un segundo y un tercer flashback en el orfanato de Lowood y un cuarto flashback que tiene lugar en el castillo de Thornfield, que es el lugar del que Jane huye.

La segunda consecuencia que se deriva del comienzo de la acción in extrema res es que de lo que se trata es de poner en primer término el dramatismo de la situación presente en la que se encuentra la protagonista, tras una peripecia ya vivida, que aún desconocemos.

Por último, con este modo de arranque narrativo, como espectadores se nos coloca en una posición en la que se mezclan la ignorancia y el saber. Por un lado, somos ignorantes con respecto a cómo la protagonista llegó hasta este punto melodramático — ¿de qué huye la joven Jane Eyre? - y no obstante, por otro lado pero de forma simultánea, sabemos que, más adelante, vamos a regresar a este momento inaugural del relato el cual, entonces, ya no será un momento de apertura hacia el pasado sino un momento de apertura hacia el futuro, hacia la resolución del presente dramático que, en principio, empuja a la heroína a huir.

La secuencia inaugural de la huida de Thornfield termina con Jane cayendo medio muerta en la puerta de la casa del párroco John Rivers, quien le salva la vida. Ya en el interior de la casa, cuando John Rivers y sus dos hermanas le preguntan cómo se llama -imágenes 5 y 6 - el relato nos desplaza, a través de un flashback subjetivo de Jane, a un momento decisivo de su infancia; concretamente al momento en el que su tiránico primo John Reed, tras perseguirla por la casa, espada en mano, la golpea con el libro que ella estaba leyendo -imágenes 7 y 8 -

El relato establece aquí lo que va a ser una constante textual, a saber: el juego de relaciones entre el presente y el pasado narrativo de Jane. En esta primera ocasión, se produce una asociación presente-pasado tanto a través de una rima significante

Todas las capturas de pantalla pertenecen al DVD distribuido por A contracorriente films. 
— los dos personajes masculinos se llaman John — como a través de una triple rima visual: en primer lugar, Jane está en ambos planos "pálida como la muerte" — imágenes 5 y 7 - como dice una de las hermanas Rivers; en segundo lugar, John — Rivers y Reed - la miran en contrapicado — imágenes 6 y 8 -; y, por último, al fondo, las dos hermanas de los dos John, contemplan la escena -imágenes 9 y 10 -.
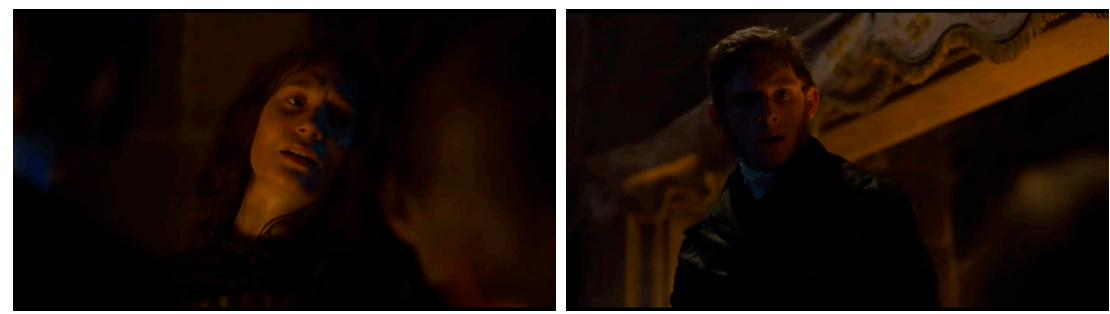

Imágenes 5 y 6. John Rivers (a su hermana): Pregúntale cómo se llama. [Fuente: captura de pantalla].
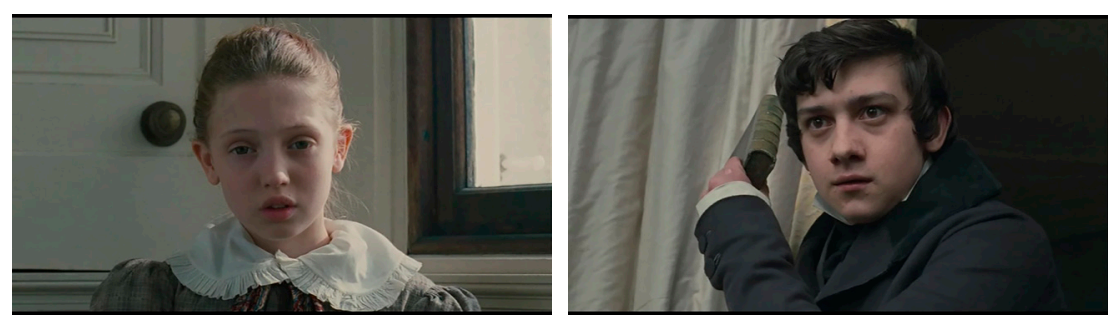

Imágenes 7 y 8. John Reed: Jane Eyre, ¿dónde estás?

[Fuente: captura de pantalla].
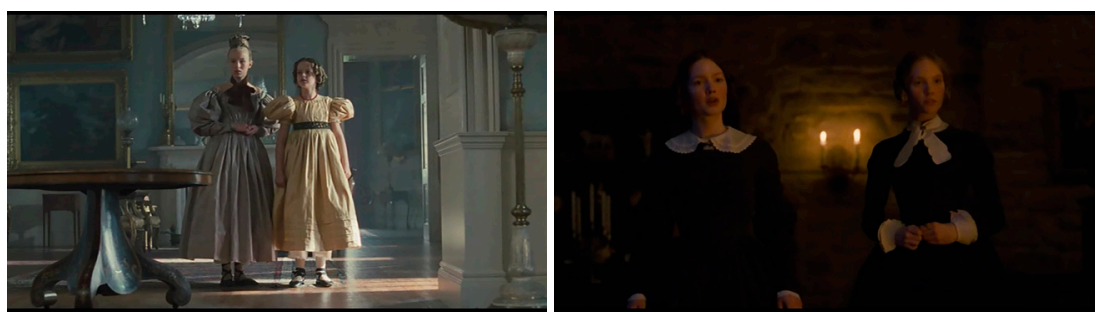

Imágenes 9 y 10. [Fuente: captura de pantalla].

Inmediatamente después de recibir el golpe en la cabeza que le propina su primo John Reed, Jane se abalanza sobre él y comienza a pegarle con todas sus fuerzas imagen 11-.

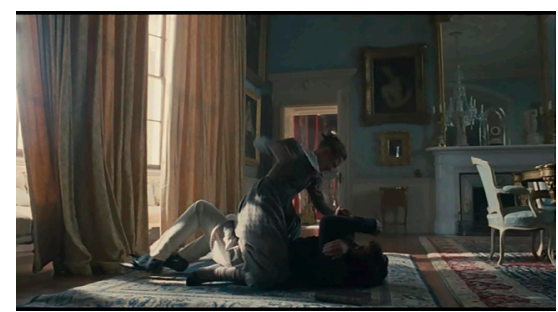

Imagen 11. [Fuente: captura de pantalla]. 
Inmediatamente después de recibir el golpe en la cabeza que le propina su primo John Reed, Jane se abalanza sobre él y comienza a pegarle con todas sus fuerzas imagen 11 -

Ante la violenta respuesta de Jane, la tía Reed ordena que la encierren en el cuarto rojo, esa estancia que, según Jane, está “embrujada". Dentro del cuarto rojo, Jane está asustada, ruega que la dejen salir, golpea la puerta con furia. De pronto, Jane escucha un extraño ruido procedente de la chimenea y mira hacia ella -imagen 12 - Entonces, un humo aterrador, negro y espeso, sale del interior de la chimenea.
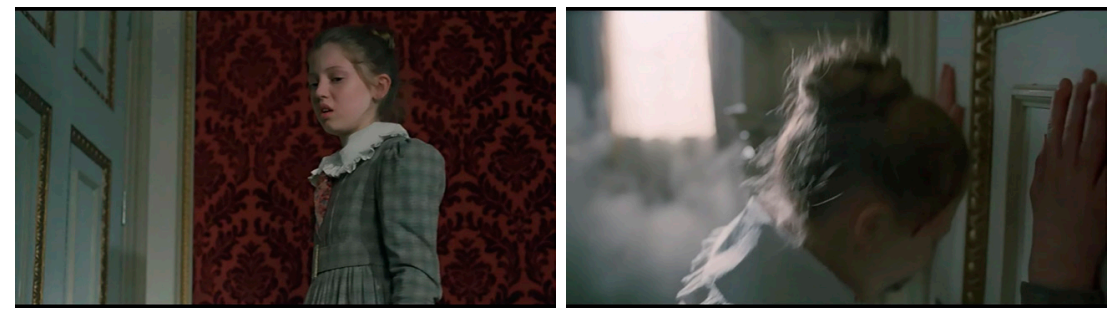

Imágenes 12 y 13. [Fuente: captura de pantalla].

Jane grita llena de angustia y de ira, no puede escapar de ese lugar, ardiente y claustrofóbico. Está atrapada, se ahoga - imagen 13-. Desesperada, sigue golpeando la puerta y, ya fuera de sí, se da un cabezazo contra la misma y cae desmayada.

La 'escena del cuarto rojo', "escena en la que tiene lugar la experiencia más vibrante desde un punto de vista metafórico de todas las primeras experiencias de Jane", sitúa en el núcleo mismo del relato el "motivo central del encierro y de la fuga"' (Gilbert y Gubar, 1979: 345-346).

Tal y como señalan Gilbert y Gubar en su análisis de la novela de Brontë,

(...) resulta evidente que Charlotte Brontë, de forma completamente consciente, ideó el incidente del cuarto rojo para que sirviera de paradigma para el argumento mayor de su novela, no solo por su posición en la narración, sino también por el recuerdo que tiene Jane de esta experiencia en momentos cruciales a lo largo del libro: cuando es humillada por el señor Brocklehurst, por ejemplo, y la noche en la que decide dejar Thornfield (1979: 345-346).

La centralidad del motivo del encierro y de la fuga, motivo que "constituye el significado por excelencia" del filme (Barthes, 2001: 12-13), viene dada por dos razones. En primer lugar, porque el tema del encierro y de la fuga está destinado a fijarse a lo largo de todos los lugares que jalonan el periplo de Jane: en la casa de la tía Reed; en Lowood - el orfanato-escuela en el que la tía Reed encierra a Jane-; en el castillo gótico de Thornfield, tal y como es propio del género; y, por último, en la casa de John Rivers, el lugar en el que, tras huir de Thornfield, Jane se "esconde" para que nadie la encuentre jamás. Y, en segundo lugar, si el motivo del encierro y de la fuga es el núcleo significante del filme es porque este motivo establece una clara conexión estructural entre dos de las escenas más significativas de la película: la 'escena del cuarto rojo' en el que Jane es encerrada por su tía — “no podría imaginarse una prisión más segura que aquella” (Brontë, 1847: 32) - y la 'escena de la huida' de Jane del castillo de Thornfield, escena que se repite tras hora y media de metraje. 
De hecho, el relato escribe una evidente rima visual entre el final de la escena del cuarto rojo - imágenes 14 y 16- y el final de la escena de la segunda huida de Jane - imágenes 17 y 19 - a través de estos dos planos cenitales del desfallecimiento — de la muerte simbólica — de la protagonista.
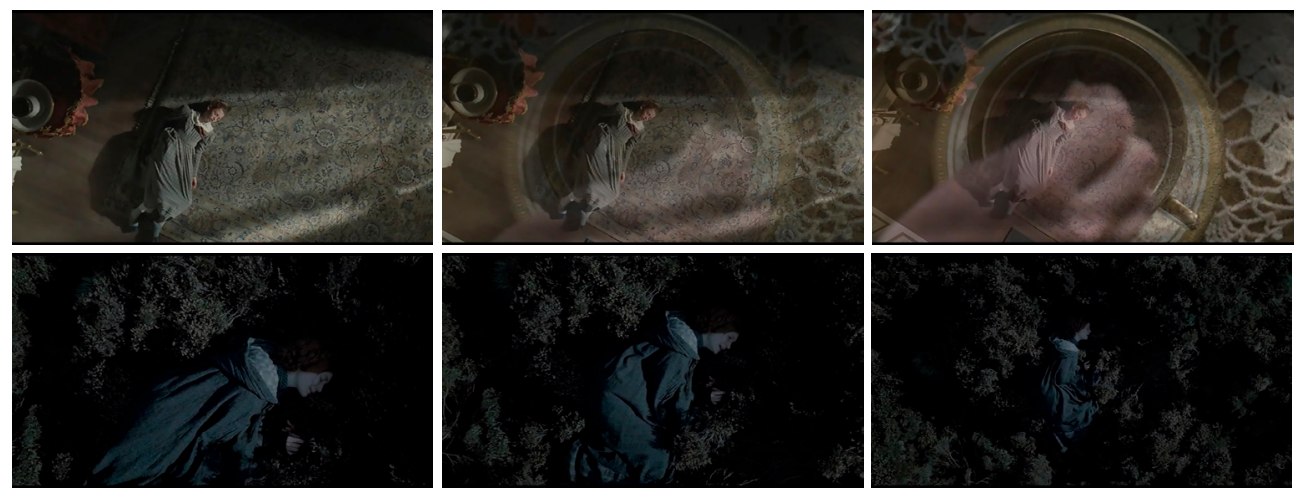

Imágenes 14 -19. [Fuente: captura de pantalla].

Inmediatamente después de la escena del cuarto rojo y, por lo tanto, en relación directa con el motivo del encierro y de la fuga, la tía Reed se deshace de Jane y la envía al orfanato de Lowood. El relato pone así, en primer término, el conflicto entre la violencia de Jane, que en este momento del filme es la violencia propia de una niña apasionada —imágenes 20 y 21 -
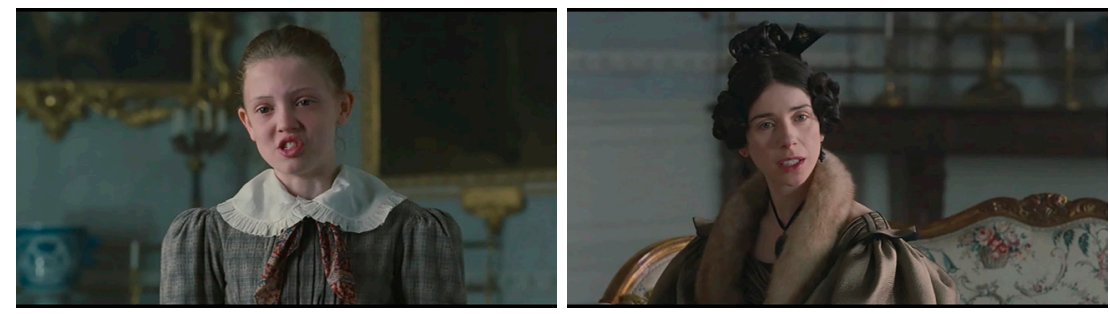

Imágenes 20 y 21.

Señora Reed: Hay que corregir los defectos de los niños. Jane: No soy una mentirosa.

Señora Reed: Pero eres apasionada (But you are passionate).

[Fuente: captura de pantalla].

y la ley moral-religiosa, ley excesiva e implacable que, tal y como se muestra en el castigo ejemplar del "pedestal de la infamia" - imagen 22- oscila entre dos polos: de un lado, la ley moral-religiosa entendida como una doctrina que, en palabras del señor Brocklehurst, apunta a "arrancar de raíz la maldad" de Jane, es decir, a aplastar su pasión; y del Otro lado, la ley moral-religiosa entendida como una doctrina que apunta a restaurar la existencia de un Otro absoluto que 'todo lo ve' (Zupančič, 2010: 162). 


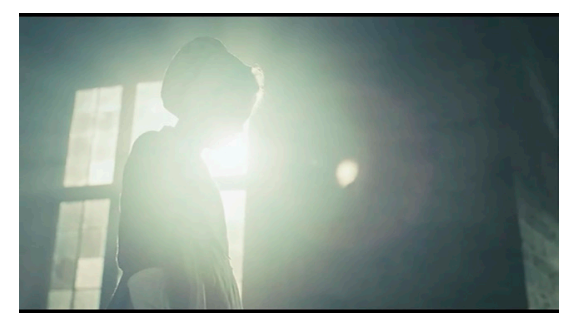

Imagen 22. [Fuente: captura de pantalla].

Este conflicto entre la ley moral-religiosa y la pasión femenina se despliega tanto en el pasado narrativo -donde el sádico señor Brocklehurst impone una "rigurosa" educación puritana basada en "mortificar la carne" de las niñas "pecadoras" a latigazos para que "se arrepientan y sean abnegadas"- como en el presente, es decir, en la casa del párroco John Rivers, que es el lugar donde se desencadenan los tres primeros flashbacks.

Ahora bien, la tensión entre la ley moral-religiosa y la pasión de nuestra heroína victoriana alcanza su máxima expresión en el cuarto y último flashback, el flashback de Thornfield; y más concretamente, en el momento en el que Jane huye del castillo, después de que Rochester la haya iniciado "en los misterios de la carne" (Gilbert y Gubar, 1979: 359).

Veamos, pues, cómo se despliega en Thornfield la tensa articulación entre el ideal moral-religioso de la pureza femenina y la cuestión del goce sexual de la mujer.

\section{Los ideales culturales}

Al poco de llegar a Thornfield, Jane, aislada del mundo exterior, encerrada tras el enrejado de la ventana del castillo como un pájaro enjaulado - imagen 23 -, le cuenta a la señora Fairfax sus más íntimos anhelos.

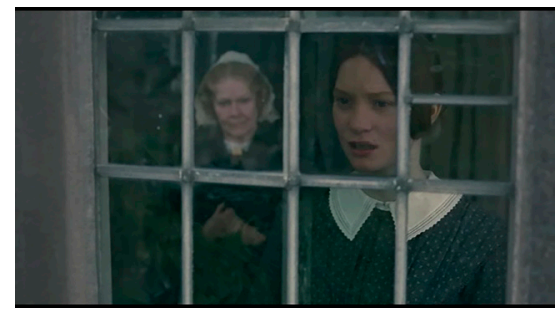

Imagen 23.

Jane: Ojalá las mujeres tuvieran acción en su vida, como los hombres. Me duele en el alma que el horizonte que hay ahí sea siempre nuestro límite. A veces anhelo tener un poder de visión que consiga sobrepasarlo. Si fuera capaz de ver todo lo que imagino... Nunca he visto una ciudad. Nunca he hablado con hombres. Y temo que se me pase la vida de largo.

[Fuente: captura de pantalla].

Jane pronuncia aquí, justo antes de que tenga lugar la aparición de Rochester, un breve discurso que es claramente feminista: "ojalá las mujeres tuvieran acción en su 
vida, como los hombres". Pero no solo eso. Al expreso anhelo feminista de Jane se anudan además otros dos anhelos: el anhelo de tener un "poder de visión" y el anhelo de "conocer hombre".

El primero - "a veces anhelo tener un poder de visión" que consiga sobrepasar el límite del horizonte-, anhelo que está literalmente escrito en la novela de Brontë (1847: 176), remite a la ya clásica reivindicación en contra de la reclusión real de las mujeres en el espacio doméstico, reivindicación compartida por la tradición de las escritoras feministas británicas. Así, por ejemplo, Virginia Woolf en su conocido ensayo Una habitación propia (1929) escribe que "ningún humano debería limitar su visión" (1986: 156).

Ahora bien, cabe señalarse aquí que este anhelo feminista de tener un "poder de visión" no deja de estar conectado a la creencia religiosa de que tal "poder de visión" existe. De hecho, Jane es retratada desde el inicio mismo del relato como una joven que cree en la mirada omnipotente de Dios-padre - imagen 24-.

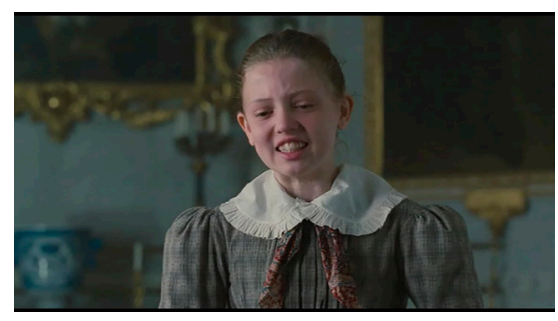

Imagen 24. Jane: Tío Reed está en el cielo, al igual que mi madre y mi padre, ellos saben que me odia y que quiere que me muera, ven todo lo que usted hace y la juzgarán, señora Reed.

[Fuente: captura de pantalla].

Esta mirada, que actúa como garante de la experiencia moral-religiosa, sostiene a Jane tanto durante su "triste pasado", como durante su estancia en Thornfield, ese lugar donde ella se dibuja a sí misma, se ve a sí misma, como la "estrella vespertina" -imagen 25-, es decir, como "un ángel" con un "manto de luz".

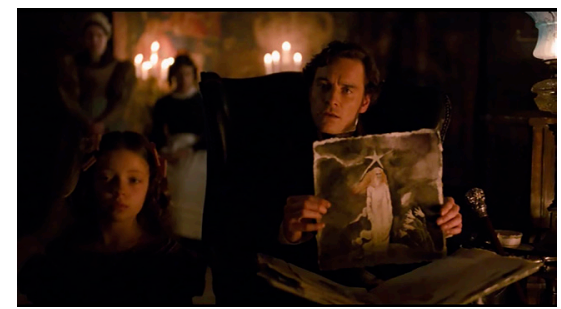

Imagen 25. [Fuente: captura de pantalla].

Diríase que bajo esta mirada divina Jane se ve a sí misma justamente como ella quiere ser vista por Rochester, esto es, como una joven "franca" y con la "conciencia limpia" - imagen 26-, 


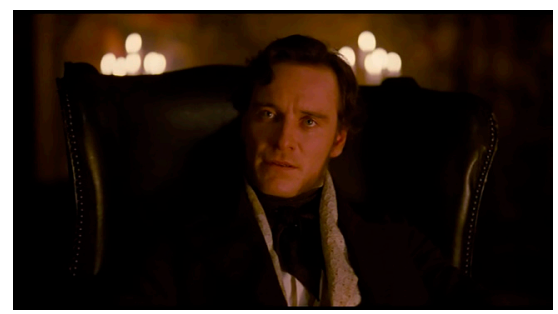

Imagen 26.

Rochester: La envidio (...) por su franqueza, por su conciencia limpia.

[Fuente: captura de pantalla]. $27-$

como una joven con quien se "podría vivir de una forma más pura" —imagen

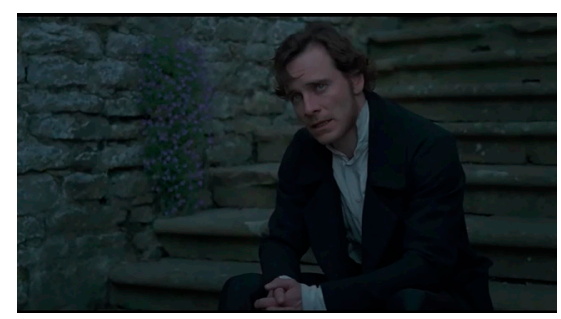

Imagen 27.

Rochester: Esta primavera llegué a casa (...) y conocí a una amable mujer cuya presencia me reanima, con ella siento que podría volver a vivir de una forma más pura.

[Fuente: captura de pantalla].

como una joven que "haría cualquier cosa" por Otro, "siempre que fuera justaimágenes 28 y 29 -
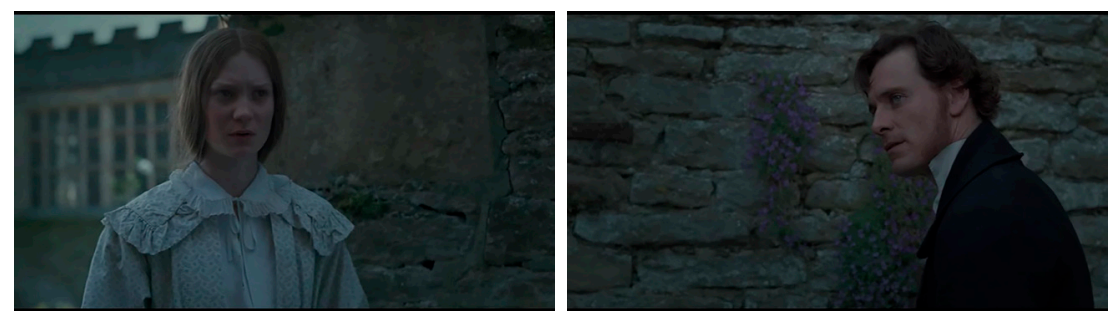

Imágenes 28 y 29. Jane: Haría cualquier cosa por usted, señor, siempre que fuera justa. [Fuente: captura de pantalla].

pero, sobre todo, como una joven "fascinante" y "excepcional", porque ella es "fresca y sana, sin tacha ni defecto" —imagen 30-. 


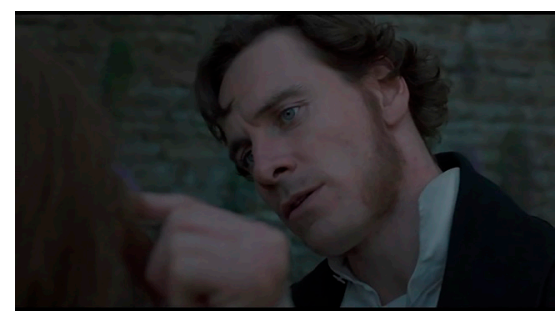

Imagen 30. Rochester: Me tiene usted fascinado. (...) Es excepcional, ¿verdad? Fresca y sana, sin tacha ni defecto.

[Fuente: captura de pantalla].

Cabría leerse que en el relato se pone en juego, así pues, una doble mirada masculina supuestamente omnipotente: de un lado, la mirada de Dios todopoderoso; y del Otro, la mirada de Rochester, mirada que, tal y como ha sido señalado por $\mathrm{M}^{\mathrm{a}}$ Eugenia Perojo, es la mirada propia del Satán de Milton (1994: 267). De hecho, en la segunda conversación que Jane mantiene con él, Rochester es retratado como un hombre que, al modo del héroe satánico-byroniano, "tiene poder de visión" puesto que, en esta escena, y para vergüenza de Jane — que se sonroja-, Rochester la atraviesa con su ardiente 'mirada de águila' y nombra con toda exactitud cuál es la realidad, tanto externa como interna, de Jane —imágenes 31 y 32 -
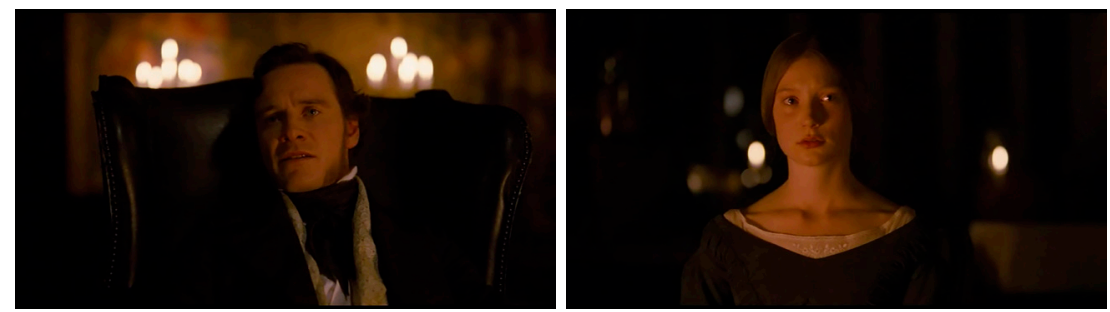

Imágenes 31 y 32. Rochester: Veo en usted la mirada de un ave curiosa a través de los barrotes de una jaula, una cautiva, inquieta y vital, pero si fuera libre se elevaría nubes arriba.

[Fuente: captura de pantalla].

A diferencia de lo que ocurre con este primer anhelo de Jane de "tener un poder de visión" - que es un anhelo que se enmarca tanto en el discurso religioso-cristiano como en la tradición literaria feminista británica-, su segundo anhelo, el anhelo de "conocer hombre", mantiene una relación mucho más compleja con la tradición feminista, en la medida en que sólo es explícitamente abrazado por el llamado 'feminismo de la diferencia', corriente política y trama teórica en la que se inscribe este artículo $^{6}$.

Cabría establecerse, en relación a este segundo anhelo de Jane, una conexión entre Jane Eyre y el mito de Psique y Cupido — relatado en la novela de Apuleyo El

6 Nótese que el movimiento feminista es heterogéneo y que, por tanto, una cosa es 'el feminismo de la diferencia' — que tuvo su momento de esplendor durante la década de 1960, la década de "la liberación sexual"- y otra cosa bien diferente es 'el feminismo de la igualdad' — que es la corriente feminista que se ha ido volviendo hegemónica desde la década de 1980, con el creciente apoyo del feminismo lésbico-. Véase Rosa María Rodríguez Magda (1994) y Celia Amorós (2000) para esta histórica heterogeneidad interna al feminismo; y Judith Butler (1999) para la creciente asociación política entre el feminismo y el movimiento lésbico. 
Asno de Oro - dada la presencia central que tiene el cuadro de Psique y Cupido en el castillo de Thornfield - imagen 33-.

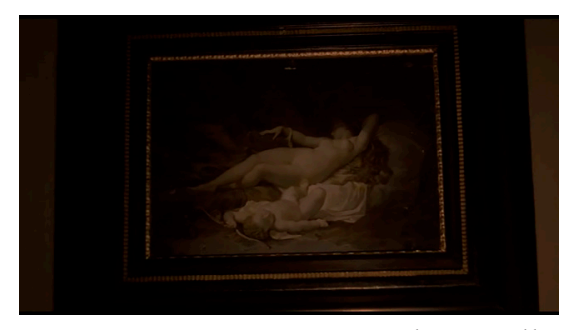

Imagen 33. [Fuente: captura de pantalla].

En ambos textos se pone en escena la mirada en su doble vertiente. De un lado, la mirada indagatoria de las jóvenes Psique y Jane -imágenes 34 y 35-, mirada que apunta a un saber sobre el goce corporal, placer que, en este cuadro, en el que la mirada subjetiva de Jane se detiene en dos ocasiones, se representa a través del voluptuoso cuerpo desnudo de Psique - imagen 36-.
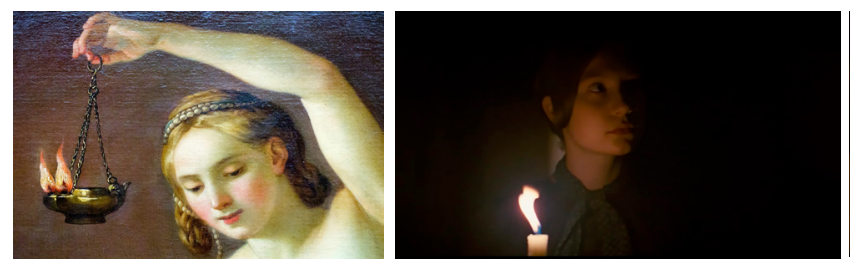

Imágenes 34, 35 y 36.

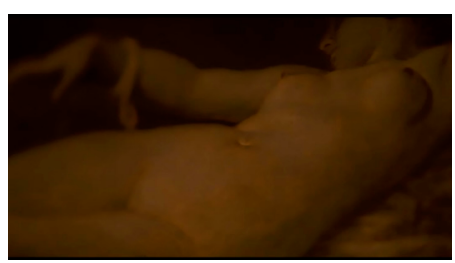

Imagen 34: fragmento de Psyché reconnaissant l'amour endormi (Joseph Marie Vien, 1761).

[Fuente: Colección de pinturas del Palais des Beaux-Arts de Lille].

[Fuente (imágenes 35 y 36): captura de pantalla].

Y del otro lado, la mirada del Otro, es decir, la mirada de Cupido y la mirada de Rochester -imágenes 37 y 38 -
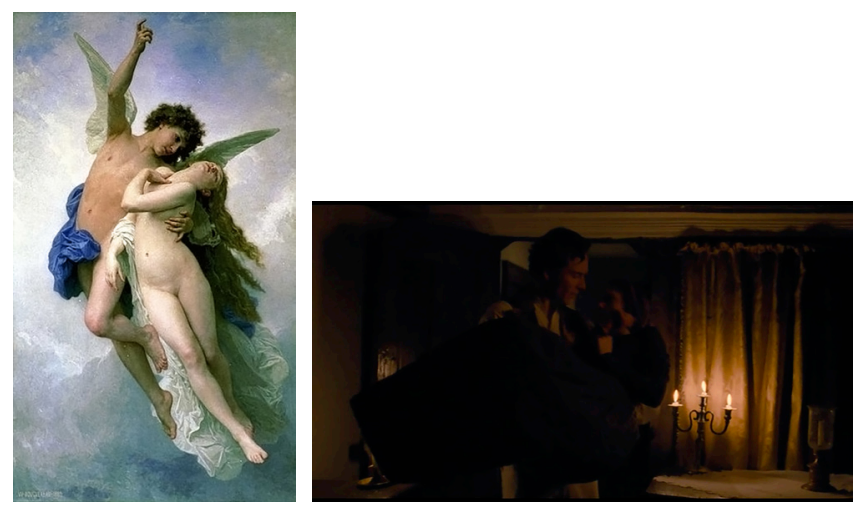

Imágenes 37 y 38 .

Imagen 37: Psyche et L'Amour (William Adolphe Bouguereau, 1889).

[Fuente: Tasmanian Museum and Art Gallery].

[Fuente (imágenes 38): captura de pantalla]. 
Pues bien, ¿y si lo que mantuviese a Jane enjaulada en el espacio doméstico, lo que no le permitiese "elevarse nubes arriba" como hace Psique, no fuese otra cosa que el hecho de que Jane no ha conocido todavía varón, que no ha experimentado todavía el goce sexual con un hombre?

Podría decirse entonces que, si bien el anhelo de Jane de "tener un poder de visión" está ligado a una potente mirada masculina que 'todo lo ve', el anhelo de "conocer hombre" está relacionado con una mirada femenina que se dirige al goce sexual, esto es, a algo que no se puede ver porque no hay significante que lo nombre, ni imagen que lo muestre (Lacan, 1962-1963: 359). Y por eso mismo, porque no hay significante que lo nombre, ni imagen que lo muestre, al final de la película, cuando Jane regresa a las ruinas de Thornfield -imagen 39- en busca del hombre que la introdujo en los misterios de la carne, se encuentra no sólo con un Rochester ciego, sino también con el cuadro de Psique y Cupido - imagen 40-, cuadro ahora vacío, pero que, no obstante, conserva la huella de lo que allí hubo; a saber: la propia mirada infantil de la heroína, mirada que comparece en el interior del cuadro por medio de la muñeca de Jane.
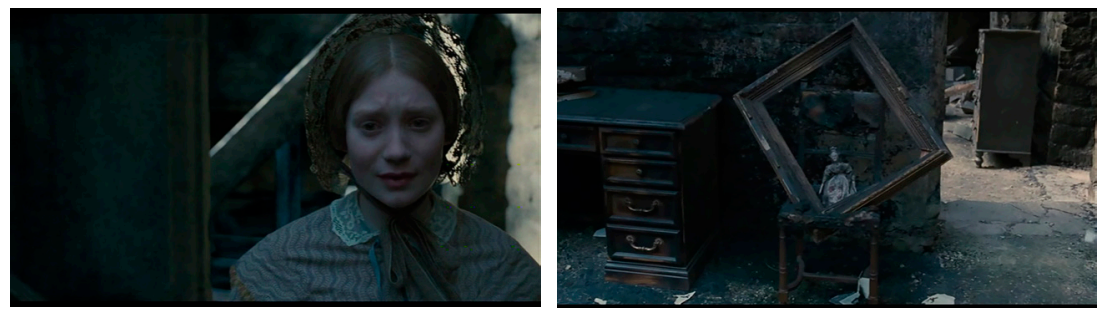

Imágenes 39 y 40. [Fuente: captura de pantalla].

\section{Sexualidad y violencia}

El castillo gótico de Thornfield no es solo el lugar en el que vemos florecer en nuestra protagonista el ideal de la virtud femenina, sino que también, tal y como el cuadro de Psique y Cupido nos anuncia, es la "casa del goce" (Lacan, 1962-1963: 83), es decir, el lugar en el que se va a poner en escena, fundamentalmente por medio de los mitos y de los cuentos de hadas - imagen 41-, la imbricación entre la sexualidad femenina y la violencia, esto es, aquello que entra en conflicto directo con dicho ideal cultural.

Después de haber pasado su primera noche en Thornfield, Jane se despierta y lo hace junto a la misma muñeca con la que había llegado a Lowood y que luego 'pierde' tras su huida de Thornfield. Y así, siendo la misma niña que era entonces, o como un poco más adelante le dirá Rochester, siendo todavía "una colegiala", comienza Jane su trabajo como institutriz de la pequeña Adèle, esa hija extranjera de Rochester, que canta una canción que anticipa el sentido de la huida de la propia Jane - imagen 42 - y que tiene, también ella, su propia muñeca metida dentro de su casa de muñecas. 


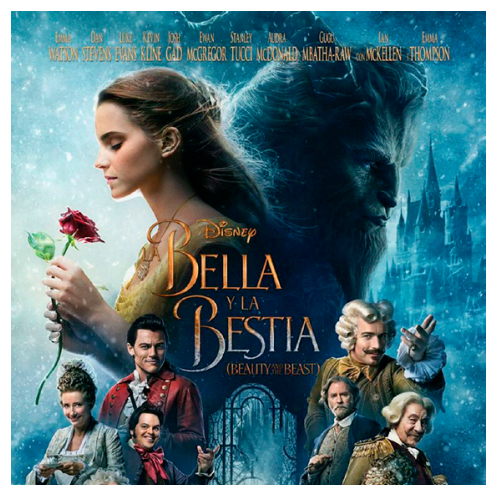

Imagen 41. Cartel de La bella y la bestia (Bill Condon, 2017)

[Fuente: captura de pantalla].

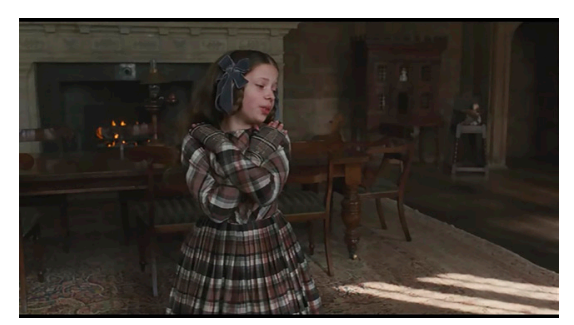

Imagen 42. ¿Cómo huir y evitarlo? La forma, Dios mío, la ignoro. Quiero resistirme, olvidarle, sí. Le quiero y le deseo todavía.

[Fuente: captura de pantalla].

Jane, habiendo dejado su muñeca en el suelo, comienza a contarle a Adèle la historia del Gytrash —imágenes 43 y 44 -.
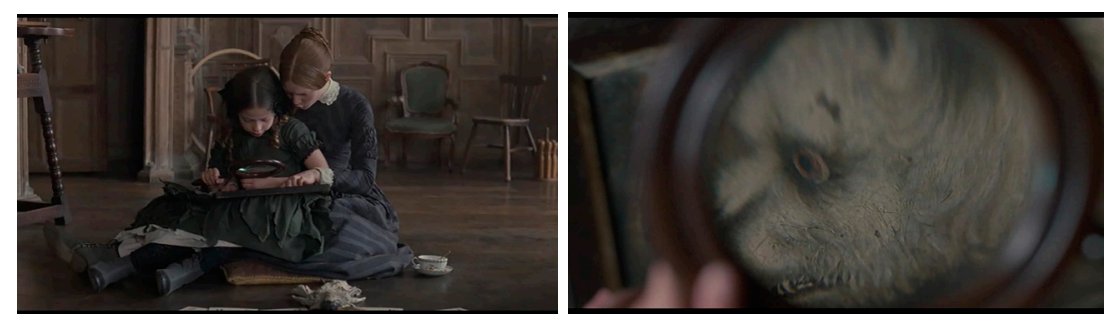

Imágenes 43 y 44 .

Jane: "Me marcharé e iré al pueblo". "Oh, no vaya", le suplicó la doncella, "porque el Gytrash vaga por esas colinas".

Adèle: ¿Qué es?

Jane: El espíritu del norte que acecha a los viajeros que pasan por allí. Habita en los esqueletos de las bestias. Adopta forma de caballo, lobo o perro gigante. Se le reconoce por sus ojos rojos como el carbón ardiente. Si alguna vez te alcanza uno...

[Fuente: captura de pantalla]. 
El Gytrash es una "aparición, espectro o fantasma", un "espíritu maligno", que adopta la forma de una "bestia feroz" (Wright, 1898-1905) y que, si lo ubicamos en el contexto de la infancia, podría venir a nombrar ese momento en el que el Otro sexo aparece bajo la forma de algo semejante a un animal terrible, algo de lo que debemos huir y escondernos (Bettelheim, 1977: 291). En esta línea, es preciso subrayar que tanto en la novela - donde se dice de forma literal - como en la película, la escena en la que Jane conoce a Rochester, es decir, la escena en la que irrumpe el Otro sexo, está recreada precisamente de acuerdo con el espíritu del Gytrash.

Jane se adentra en un inquietante bosque, oscuro y amenazante. Está asustada y excitada, jadea. La niebla se espesa. Se oyen toda una serie de sonidos extraños. La imagen se ralentiza. Aparece de pronto un caballo relinchando que parece que va a abalanzarse sobre ella -imagen 45-. Jane, temerosa, se aparta y, entonces, el caballo se encabrita y, como si hubiese sido "embrujado" por Jane - tal y como le dice Rochester más adelante-, cae hacia atrás tirando al suelo al jinete.

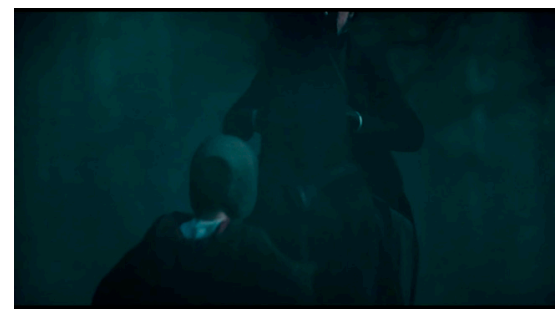

Imagen 45. [Fuente: captura de pantalla].

El encuentro entre Jane y Rochester - anticipado en la escena previa de la ventana del castillo - no es un encuentro como el del cuadro de Pisque con Cupido, relajado y caluroso, sino que es abrupto y frío; está marcado por el miedo de Jane ante ese misterioso jinete, lo peligroso del caballo desbocado y la consiguiente reacción furibunda del hombre desconocido: “¿De dónde sale usted?”-le increpa Rochester enfadado-. Pero la cosa no queda ahí, ya que esta misteriosa atmósfera no solo impregna el momento en el que Jane y Rochester se conocen, sino que para Jane - como para la joven Psique-, al menos durante su estancia en Thornfield, el Otro sexo aparece como si fuera el Gytrash, esto es, como un ser irreal, como una ensoñación, como un espectro "fantasmal", tal y como ella misma le dice a Rochester en esta otra escena -imagen 46- que no es sino una versión dulcificada del primer encuentro de la pareja.

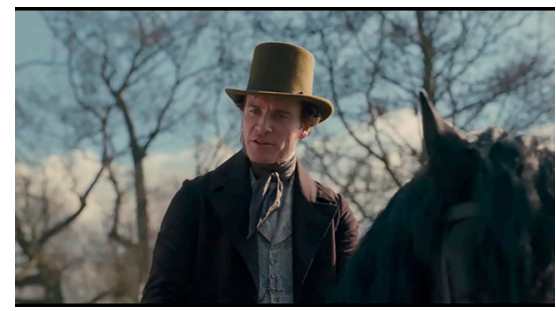

Imagen 46.

Jane: Todo parece irreal

Rochester: Yo soy muy real.

Jane: Usted, señor, es lo más fantasmal de todo.

[Fuente: captura de pantalla]. 
Ahora bien, si el espíritu del Gytrash envuelve la relación entre Jane y Rochester, este espíritu está igualmente presente en la historia que la niña Adèle le cuenta a Jane - imagen 47- sobre esa otra mujer que, como la muñeca de Adèle, está encerrada en Thornfield y se pasea por los pasillos del castillo de noche.

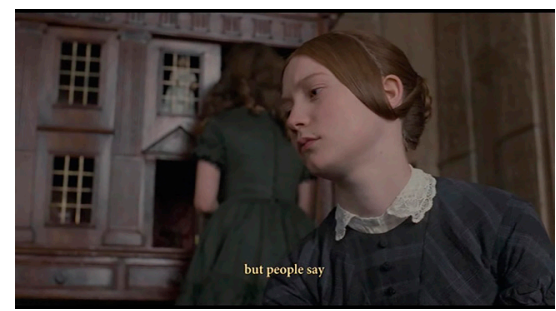

Imagen 47.

Adèle: Sophie me dijo que había una mujer que paseaba por los pasillos de esta casa de noche. Nunca la he visto, pero se dice que tiene el pelo negro como el ébano y la piel blanca como la luna y los ojos como zafiros. También puede atravesar paredes. Dicen que viene a chuparte la sangre.

[Fuente: captura de pantalla].

Observemos esta serie de tres planos que riman visual y narrativamente y que giran en torno al tema del 'encierro' en esa casa de muñecas que es el castillo de Thornfield.
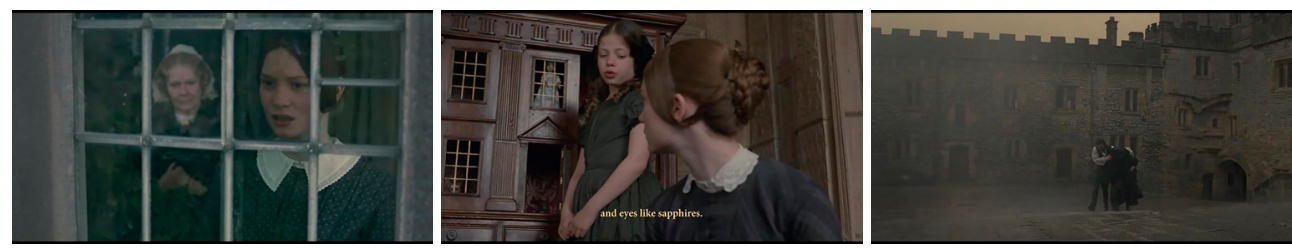

Imágenes 48, 49 y 50.

[Fuente: captura de pantalla].

Tenemos, en primer lugar, a Jane tras el enrejado de la ventada del castillo anhelando conocer hombre, es decir, saber, como la mítica Psique, acerca del goce sexual - imagen 48 - En segundo lugar, tenemos la historia de Adèle acerca de esa mujer, Bertha Mason, que - como la propia Jane y como la muñeca de Adèle- está encerrada en el castillo y se pasea por los pasillos de noche -imagen 49-. Y en tercer y último lugar, la presencia, en el mismo plano, de Bertha y de Jane: Bertha mirando por la ventana del castillo; y Jane quien, tras haber conocido hombre, ya no está en la posición de la mujer que mira, sino que está en la posición de la mujer que es mirada y, por tanto, deseada -imagen 50-.

En la historia de Adèle, la mujer que habita en el castillo adopta la forma de una mujer fantasmagórica que, cual vampiresa, te chupa la sangre. La imagen fantasmática del vampiro evoca, ya de entrada, un acto erótico y violento en el que el agresor o la agresora encuentra en el Otro el alimento y la fuente de su goce ${ }^{7}$. Al final de su

Tal y como señala Jenaro Talens, el tema del vampiro adquiere especial relevancia en el periodo victoriano, “ese periodo tan represivo en materia de sexualidad y de moral pública", en tanto permite representar una concepción de la sexualidad que las rígidas normas sociales impiden hacer explícita (2007: 285-286). 
historia, Adèle, bromeando, se acerca al cuello de Jane como para morderla -imagen 51-mientras que escuchamos el gruñido de un lobo o quizás, más bien, de una loba hambrienta.
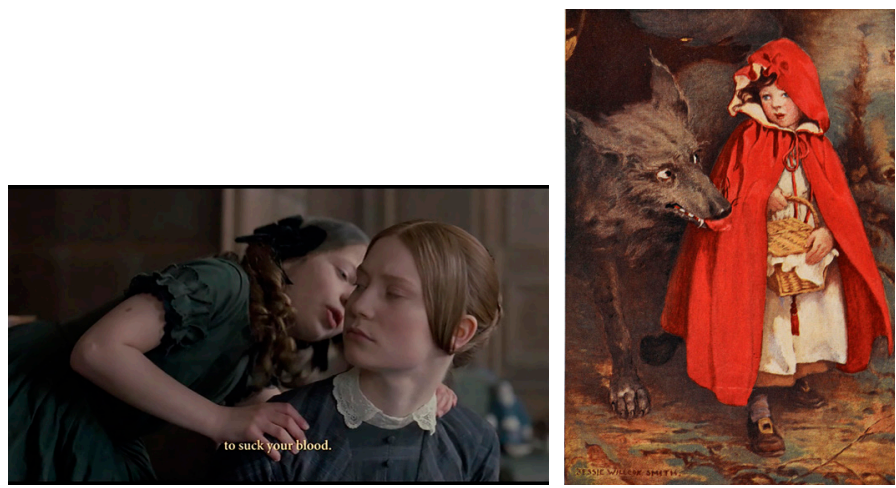

Imágenes 51 y 52.

Imagen 52: Ilustración del libro Little Red Riding Hood (Jessie Willcox Smith, 1911).

[Fuente: captura de pantalla].

Pues bien, en conexión tanto con el Gytrash - y, por lo tanto, con el encuentro romántico y terrorífico entre Jane y Rochester en el bosque crepuscular-, como con esa misteriosa mujer-vampiro que habita en el castillo, van a acontecer en Thornfield, en medio de la noche, dos extraños sucesos que están interrelacionados: el primero es el incendio en la habitación de Rochester y el segundo es la agresión a Richard Mason, el hermano de Bertha Mason.

Después de que Rochester, en la segunda conversación que Jane y él mantienen en el salón, ponga a Jane nerviosa haciéndole saber que él desea "buscar" "un placer" "dulce y fresco" con ella, Jane se va a su dormitorio. Ya dentro de la cama - tras haber contemplado por segunda vez el cuadro de Psique y Cupido-, Jane trata de dormir, pero no puede - imagen 53-.

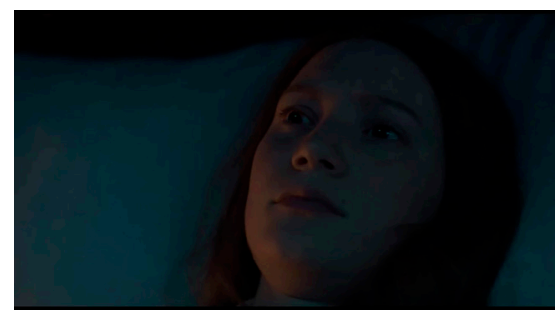

Imagen 53. [Fuente: captura de pantalla].

¿Son las provocadoras palabras de Rochester lo que la mantienen despierta? "Diríase que ello — la llamada del sexo- clama" (González Requena, 1995: 26). Se oyen, entonces, unas risas fantasmagóricas de mujer. Siguiendo estas risas, Jane, en camisón, es conducida al dormitorio de Rochester donde, justamente, la cama arde -imagen 54-. 


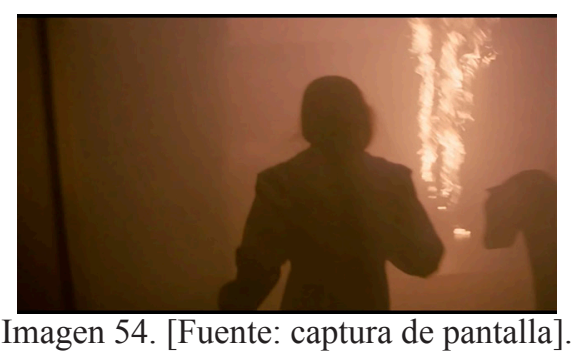

Podríamos decir que el incendio en el dormitorio de Rochester escribe metafóricamente el ardiente deseo sexual entre Jane y Rochester a través de la cama en llamas, el plano medio de Rochester fijando su mirada en el cuerpo de Jane -imagen 55 - y el plano posterior de ellos a punto de besarse - imagen 56-.

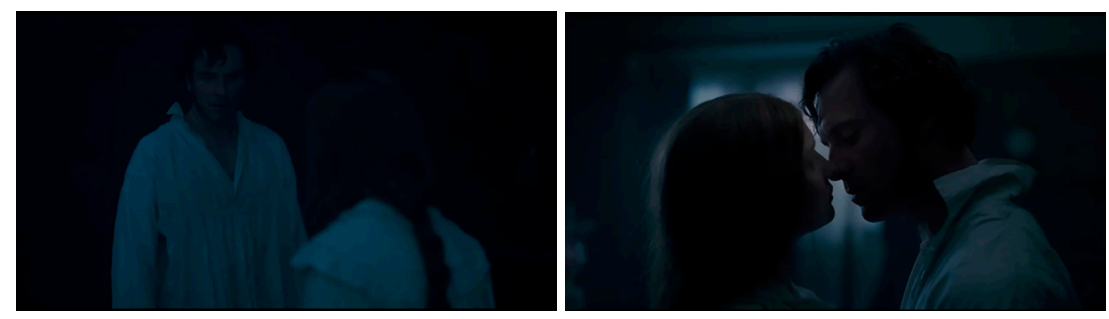

Imágenes 55 y 56. [Fuente: captura de pantalla].

En esta escena, Jane se enamora. Sin embargo, Rochester desaparece. La deja sola en Thornfield, con todo el peso de la angustia, como se muestra en la secuencia en la que Jane camina cabizbaja por los laberínticos jardines de Thornfield mientras suena una melancólica música de piano.

Después de un tiempo, Rochester vuelve a aparecer, solo que acompañado por la señorita Ingram y el resto de sus invitados de clase alta. Jane, entonces, de vuelta a su tediosa realidad de institutriz, no solo escucha cómo la llaman "demonio detestable", "histérica", "degenerada" y "raza deprimente", sino que además es testigo de "la escenita del piano" entre Rochester, este hombre voluble y experimentado en las cosas del amor, y la señorita Ingram, una repolluda mujer que, tal y como reconocerá luego Rochester, es "una máquina sin sentimientos".

Desplazada y humillada por la señorita Ingram, Jane se levanta y se va, siendo, acto seguido, felizmente perseguida por Rochester. Esa misma noche, en relación causa-efecto con el desprecio padecido en el salón, así como con el flirteo de Rochester con la señorita Ingram junto al piano, vuelven a escucharse unos sonidos extraños que despiertan a Jane - imagen 57-.

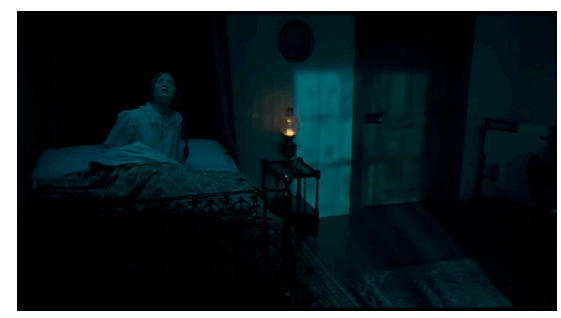

Imagen 57. [Fuente: captura de pantalla]. 
En este momento, tiene lugar, fuera de campo, la agresión a Richard Mason, agresión que queda escrita tanto en el plano detalle que muestra la profunda herida de cuchillo en la espalda del hombre -imagen 58-, como en el plano de las dos heridas de mordedura 'vampírica' en su cuello —imagen 59-.
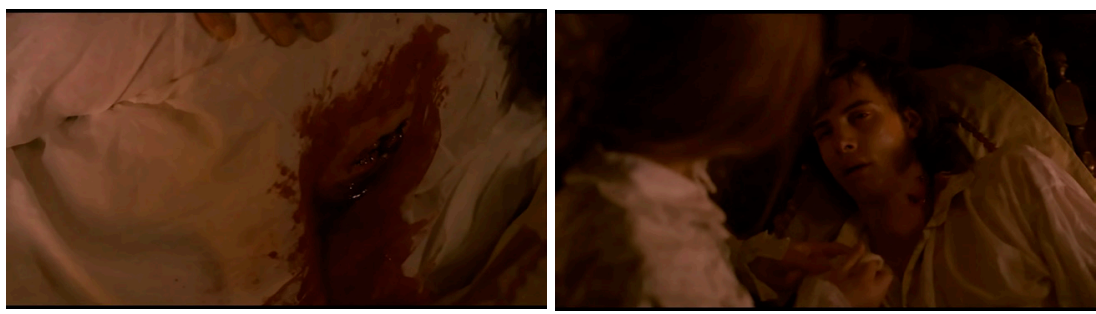

Imágenes 58 y 59. [Fuente: captura de pantalla].

Cabe leerse, entonces, la escena de esta agresión como el reverso de la escena del incendio, puesto que las dos escenas involucran el sexo y la muerte ${ }^{8}$ : en el encuentro romántico, con el incendio de fondo, Rochester está a punto de morir asfixiado; mientras que las mordeduras en el cuello de Richard Mason son, de acuerdo con el mito del vampiro, una enorme fuente de satisfacción sexual.

Cuando Jane, obedeciendo a Rochester, se dispone a curar las heridas de Richard Mason, ella vuelve a escuchar -ahora con mayor intensidad-aquellos gritos extraños y espectrales que la habían despertado en la secuencia anterior. El relato introduce en este momento el motivo clásico, presente ya en el cuento de Perrault Barbazul, de "la habitación prohibida", habitación en la que está encerrada Bertha Mason, esa mujer vampírica y fantasmal que, podríamos decir, viene a reactivar la pesadilla del encierro y el sueño de huida de la propia Jane.

Jane avanza lentamente hacia la habitación contigua, como imantada por esos inquietantes alaridos, y encuentra, tras unas gruesas y lúgubres cortinas, una puerta cerrada. La joven Jane se acerca a la puerta - imagen 60 - y la mujer encerrada al otro lado profiere un largo y ahogado aullido que recuerda al de una violenta fiera aprisionada. Jane puede escucharla, pero no puede verla. Y, sin embargo, Jane, como hiciera en la escena del cuarto rojo, mira fuera de campo y sus ojos se desorbitan -imagen 61-.
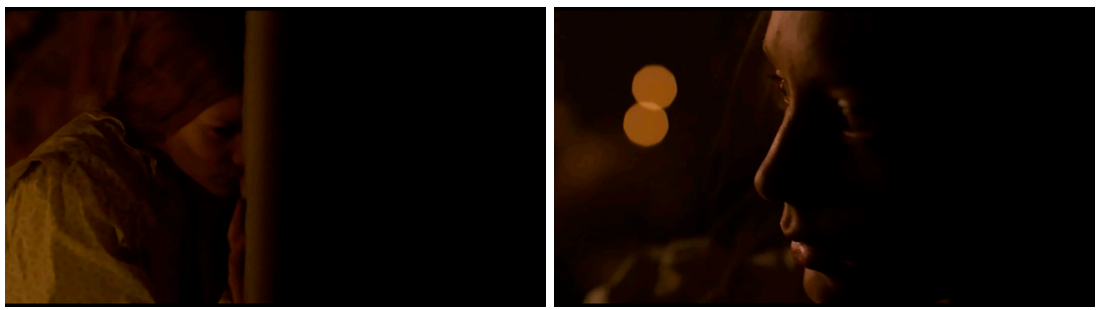

Imágenes 60 y 61. [Fuente: captura de pantalla].

Recordemos, en este sentido, que, tal y como señala Freud en Compendio del Psicoanálisis, el acto sexual es "una agresión con el propósito de la más íntima unión" pero que "un exceso de agresividad sexual basta para convertir al amante en un asesino perverso." (Freud, 1938 [1940]: 3382). 
¿Acaso no late aquí, en el momento en el que Jane se acerca a la habitación prohibida - el ático donde está encerrada Bertha Mason-, la escena en la que Jane de niña está encerrada en el cuarto rojo gritando angustiada y golpeando la puerta con furia - imagen 62-?

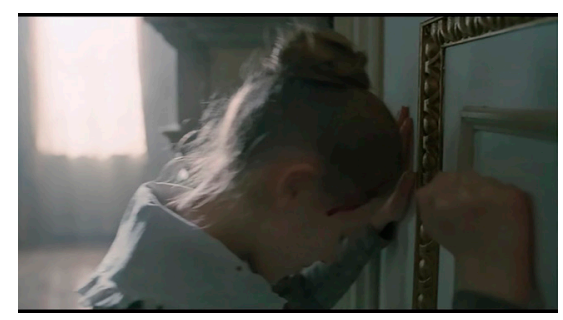

Imagen 62. [Fuente: captura de pantalla].

No hay aquí un flashback hacia la infancia de Jane dentro del flashback de Thornfield, pero podría haberlo dada la rima narrativa, visual y sonora que se establece entre la escena del cuarto rojo, protagonizada por Jane, y las dos acciones que lleva a cabo Bertha Mason cuando se fuga por las noches. Diríamos, en este sentido, que las marcas significantes de aquella fundamental escena infantil en la mansión de la tía Reed retornan en el incendio del dormitorio de Rochester y en la agresión a Richard Mason, aunque lo hacen de un modo en el que la insatisfacción es sustituida por la satisfacción. Por un lado, el irrespirable humo que salía de la chimenea del cuarto rojo - imagen 63- vuelve en el incendio de la alcoba de Rochester como señal de la pasión sexual —imagen 64 - ; y, por otro lado, tanto la espada amenazante que empuñaba su primo John Reed como la sangre que brotaba de la frente de Jane —imagen 65-, regresan en el apuñalamiento a Richard Mason —imagen 66-.
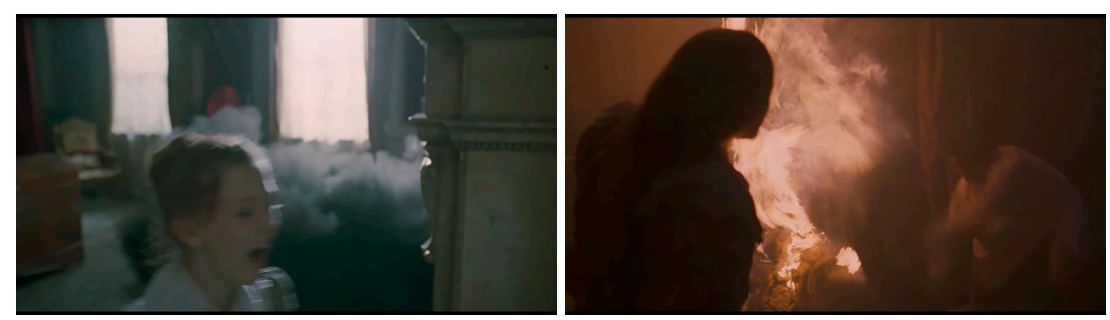

Imágenes 63 y 64. [Fuente: captura de pantalla].
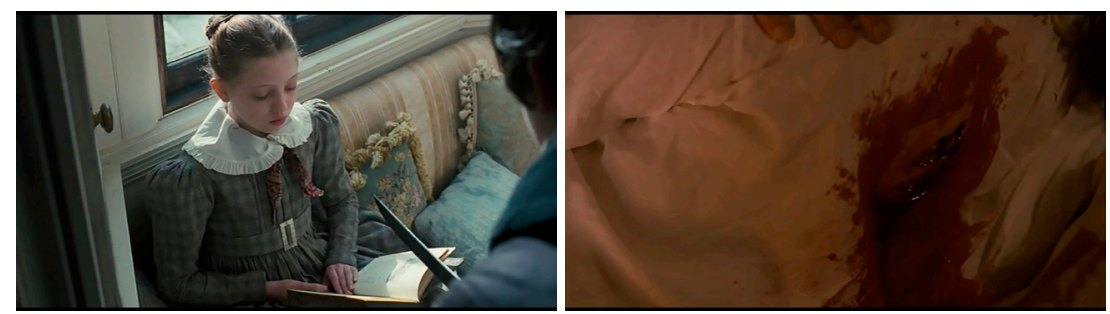

Imágenes 65 y 66. [Fuente: captura de pantalla].

La conexión significante entre, por un lado, la escena fundamental del cuarto rojo y, por otro lado, los dos actos de la lunática Bertha Mason —el incendio y las mordeduras vampíricas - es lo que nos da pie a interpretar que lo que acontece en el 
castillo gótico no es sólo el retorno de la violencia de Jane, de su "hambre, rebelión y furia" aprisionadas (Gilbert y Gubar, 1979: 366), sino también y, principalmente, el anudamiento extra-moral entre esta violencia y la satisfacción sexual.

Este lazo que une la violencia y la sexualidad queda asimismo escrito en el texto en dos momentos que riman visual y narrativamente. Primero, en la secuencia en la que Rochester le pide matrimonio a Jane, puesto que es el arrebato de cólera de Jane -imagen 67- lo que provoca el tórrido y esperado beso de la pareja -imagen 68 -
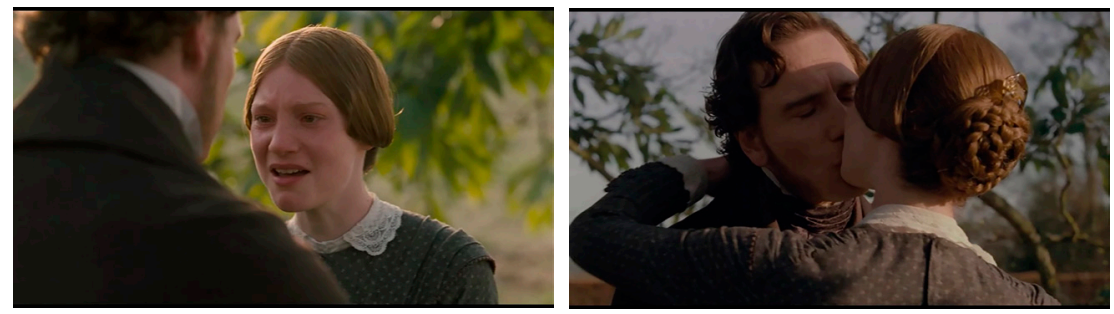

Imágenes 67 y 68. [Fuente: captura de pantalla].

Y segundo, en la secuencia en la que, tras ponerse en evidencia la fraudulenta proposición de matrimonio de Rochester, él arrastra a Jane al ático en el que está encerrada Bertha Mason y allí dentro Jane contempla el violento deseo sexual de Bertha hacia Rochester —imágenes 69 y 70 -.
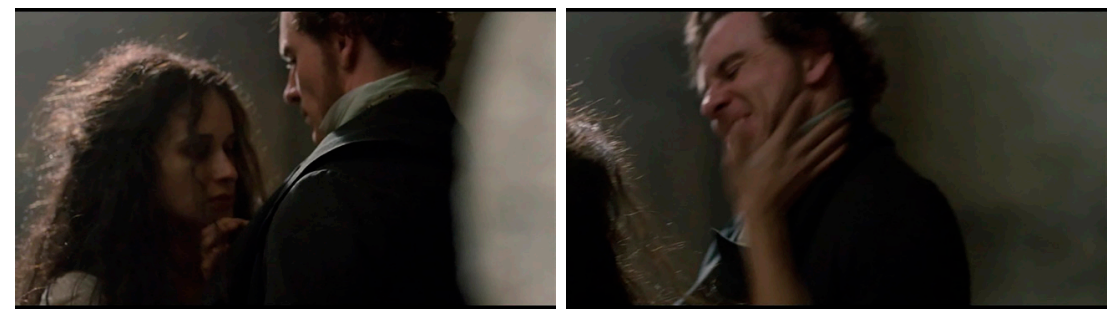

Imágenes 69 y 70.

Rochester: Ella es Bertha Antoinetta Mason. Mi demonio personal.

[Fuente: captura de pantalla].

Ahora bien, si bien es cierto que el relato parece poner en juego una cierta homología entre los personajes de Jane y Bertha - de hecho, se ha leído que Bertha Mason es la encarnación del "doble oscuro" o "yo secreto" de la protagonista (Gilbert y Gubar, 1979: 363) — , desde nuestro punto de vista, el personaje de Bertha Mason va más allá del motivo del doble, puesto que lo que esta Otra mujer vendría a encarnar es la substancia del goce sexual que amenaza a la protagonista, y que aquí estaría representada por esa extraña mosca que Bertha escupe a Jane —imagen 71 — y que queda viscosamente pegada a su virginal vestido de novia —imagen 72 - 

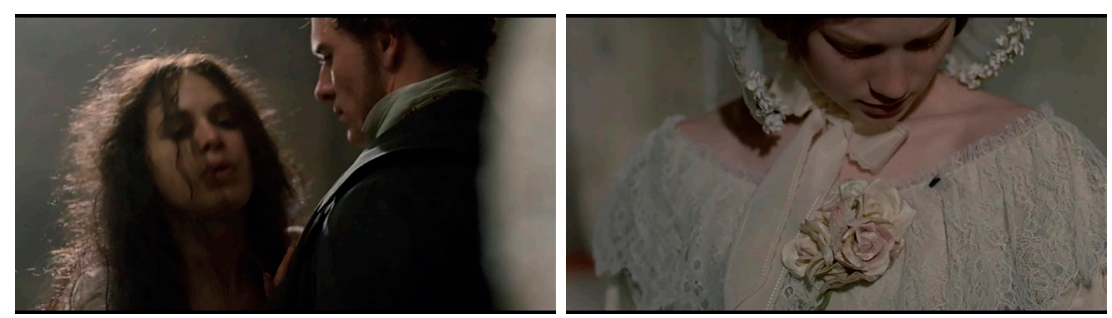

Imágenes 71 y 72. [Fuente: captura de pantalla].

La cuestión, entonces, es que este anudamiento violencia-sexualidad que se produce en el momento en el que Jane atraviesa la puerta de la habitación prohibida, es decir, en el momento en el que Jane se aproxima 'demasiado' al goce excesivo y “demoníaco", entra en conflicto directo con el ideal de 'ser' — vista por el Otro- como una mujer 'sin mancha', es decir, como una mujer "sin tacha, ni defecto".

\section{La ley del deseo versus la ley moral-religiosa}

El encuentro entre Bertha y Jane viene a reforzar, así pues, el conflicto que late en el filme entre la pasión "demoníaca" de nuestra joven protagonista y el ideal moral de la virtud y de la abnegación femenina, y nos permite, por ende, cernir el sentido de la huida de Jane del castillo.

Jane se va del ático de Bertha y desabrocha apresuradamente las ataduras de su vestido de novia. Después de unas horas, cuando sale de su alcoba, Rochester la coge en brazos -imagen 73 - como se coge a la novia en la noche de bodas y, tras un fundido a negro - imagen 74-, hay un plano detalle de él encendiendo el fuego -imagen 75-.
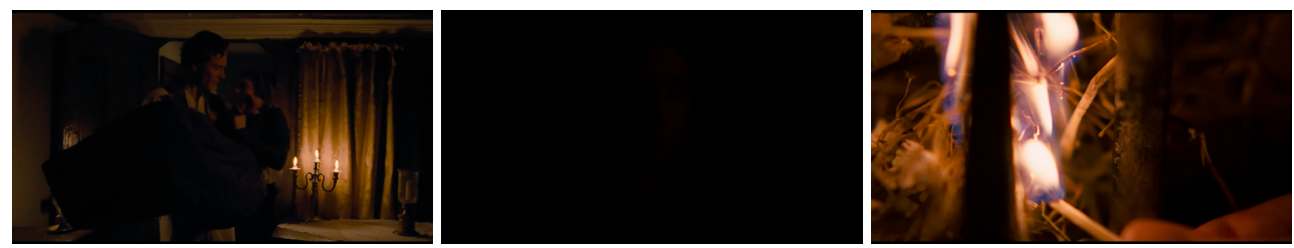

Imágenes 73, 74 y 75. [Fuente: captura de pantalla].

El acto sexual no ha sido mostrado y, sin embargo, ha sido designado y localizado. Rochester, consumada la experiencia sexual, y después de saber que Jane le sigue amando, le pide que viva con él en concubinato - imagen 76-. Pero Jane le rechaza porque, según le dice, "debe respetarse a sí misma" — imagen 77_. 


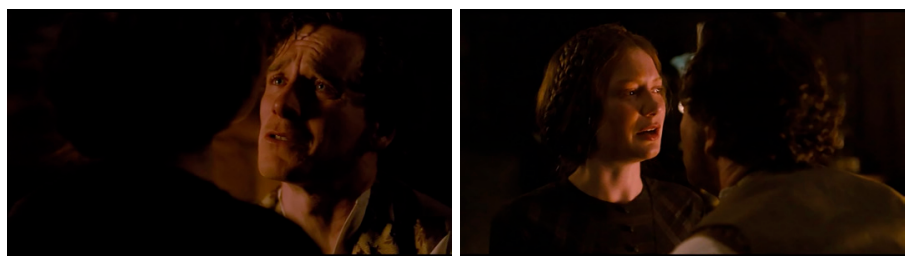

Imágenes 76 y 77.

Rochester: ¿a quién ofenderías viviendo conmigo? ¿prefieres conducirme a la locura que quebrantar una simple ley humana? Jane: debo respetarme a mí misma

[Fuente: captura de pantalla].

Rochester, entonces, dado que no puede liberarla de "su jaula", dado que no puede liberarla de ese imperativo moral-religioso — “debo respetarme a mí misma”-, que es lo que le impide echar a volar nubes arriba como hacía Psique, amenaza con matarla -imagen 78 -.

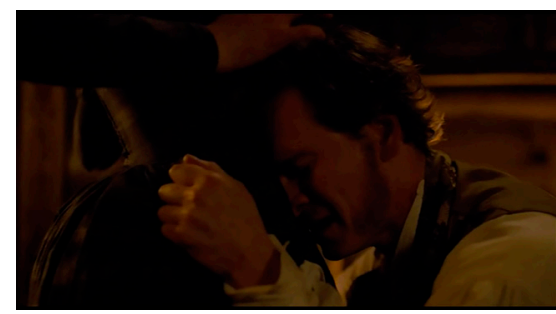

Imagen 78.

Rochester: podría doblegarte con solo dos dedos. En mis manos serías como un simple junco. Pero haga lo que haga con esta jaula, no puedo llegar a ti.

[Fuente: captura de pantalla].

Y Jane, en este momento, en una clara apelación a la cercana "presencia" de la instancia moral-religiosa, le pide ayuda a Dios —imagen 79-, e, inmediatamente después, huye —imagen 80 -
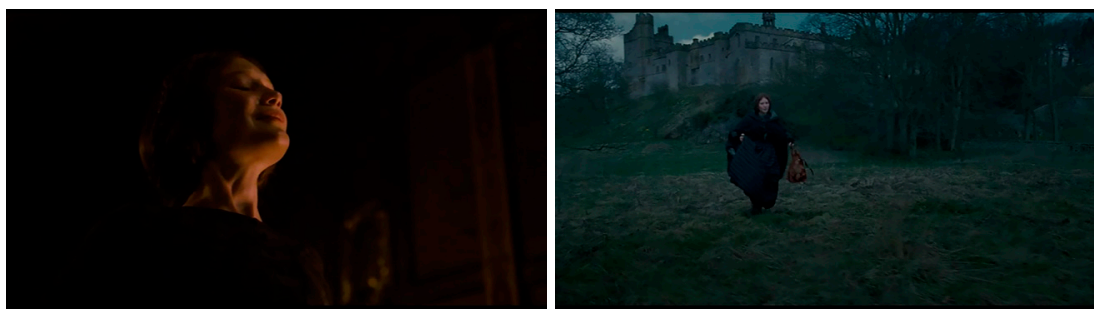

Imágenes 79 y 80 .

Jane: ique Dios me ayude!

[Fuente: captura de pantalla].

La huida de Jane puede leerse, entonces, como una acción que cumple la función de retratar a la protagonista como una joven que fundamentalmente se somete a la ley moral-religiosa, ley que la aleja de su deseo, esto es, de la pasión 'demoniaca' e "ilícita" que siente hacia Rochester. 
Toda la última parte de la película, tras la secuencia de la huida, gira en torno a la oposición estructural entre la 'ley del deseo', representada por Rochester, y 'la ley moral-religiosa', representada por el párroco John Rivers, quien, tras la secuencia de la huida, aconseja a Jane que, como él mismo hizo, no sucumba a la "tentación de mirar atrás".

Esta oposición entre la 'ley del deseo' y la 'ley moral-religiosa' encarnada por los dos antagonistas masculinos se pone de manifiesto de forma explícita en la secuencia en la que la heroína fantasea que quien llama a la puerta de su casa en medio de la noche es Rochester - a quien besa apasionadamente- y no John Rivers, quien llega con la 'buena nueva' de que Jane se ha convertido en una rica heredera.

Frente a la irreverente propuesta de matrimonio de Rochester, el párroco John Rivers, la misma noche en la que predica que hay que seguir el camino "más duro", el camino "del deber" — imagen 81 - , le propone a Jane un matrimonio moralmente irreprochable, un 'matrimonio de espiritualidad'.

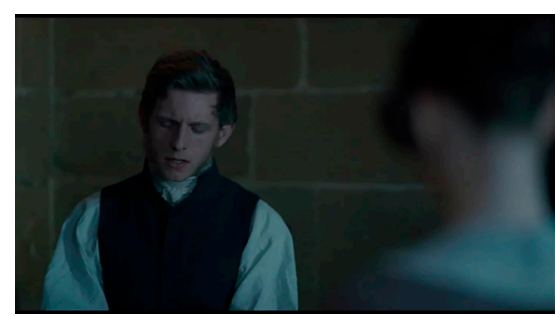

Imagen 81 .

Rivers: ayúdamos a elegir el camino más duro, al igual que nuestro maestro sufrió, también debemos sufrir nosotros. Amén.

[Fuente: captura de pantalla].

El firme rechazo de Jane a la propuesta de matrimonio del pastor, así como la encendida discusión que ambos mantienen en torno a la pasión "del amor", saca a la luz la cara más oscura de la ley moral-religiosa - imágenes 82 y 83 - una ley que, en aras de ese perseguido ideal de perfección femenina, exige el "sacrificio" absoluto e incondicional de la pasión de Jane por Rochester a un Otro - ya sea Dios, o ya sea el Deber- que se supone que existe.
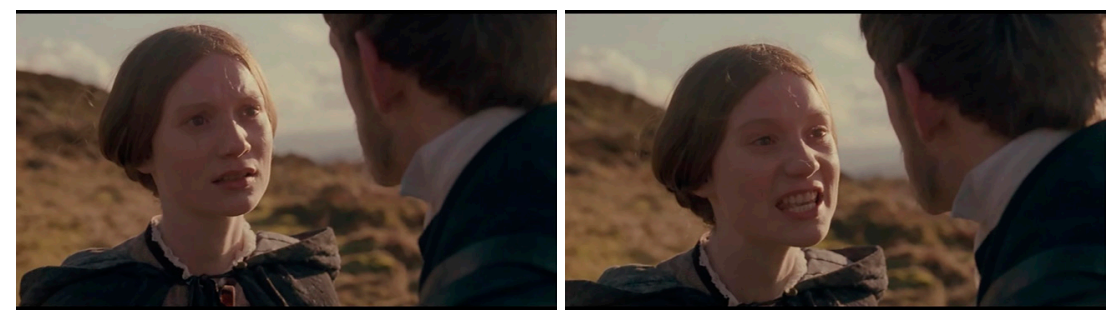

Imágenes 82 y 83 .

John Rivers: No puedes dar medio sacrificio. Debes darlo todo.

Jane: Casarme contigo me mataría.

John Rivers: ¿Te mataría?, ¿te mataría? ¡Esas palabras no son ni femeninas ni ciertas! Sé a dónde mira y a quién se aferra tu corazón. Di su nombre, ¡dilo!, ¡idilo!! ¿Por qué no has matado esa pasión ilícita? Me ofende a mí y ofende a Dios.

[Fuente: captura de pantalla]. 
Cabe destacarse en este sentido que, durante esta misma conversación en la novela, el párroco, presentándose como un 'mero instrumento' de la Voluntad de Dios, le dice a Jane:

no olvide que, si la rechaza [su proposición de matrimonio], no es a mí a quien está rechazando sino a Dios. Por mediación mía, Él le está brindando un camino de perfección, al que solo podrá acceder convirtiéndose en mi esposa (Brontë, 1847: 625).

En este momento del filme, momento en el que John Rivers pretende atribuir ese "deber de sacrificarlo todo" a Dios - como si dijera, "yo solo exijo tu sacrificio porque Él quiere que lo haga"-, tiene lugar para Jane la caída de la ley moral-religiosa, caída que da lugar a un cambio de posición de la protagonista con respecto a ese "debo respetarme a mí misma", que le dice a Rochester antes de huir.

Jane, habiéndose liberado del "deber" de seguir el "camino de perfección" que le marca y exige el párroco, camino que se inscribe en el horizonte mismo de la muerte - "casarme contigo me mataría"-, ya puede escuchar, alto y claro, la penetrante voz de Rochester llamándola —imagen 84-, voz que vendría a ser la 'voz de su propio deseo'.

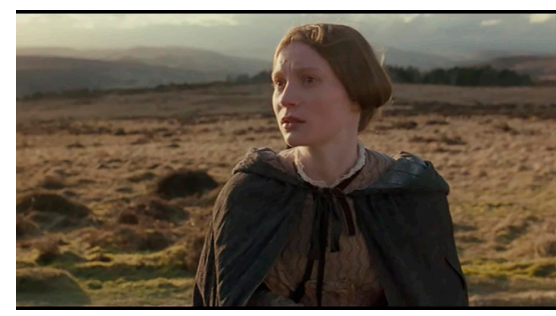

Imagen 84.

Rochester (off): Jaaanee, Jaaanee.

Jane: ¿Qué ocurre? ¿Dónde estás? Espérame. Ya voy.

[Fuente: captura de pantalla].

Es esa voz, de la que es imposible huir, lo que impulsa a Jane de nuevo a correr -imagen 85-, aunque ahora ya no lo hace sin dirección, como sucedió cuando huía de Thornfield, sino que, por el contrario, lo hace en la dirección que le señala su irrefrenable pasión por el cuerpo, que no por la mirada, de Rochester - imagen 86 -.
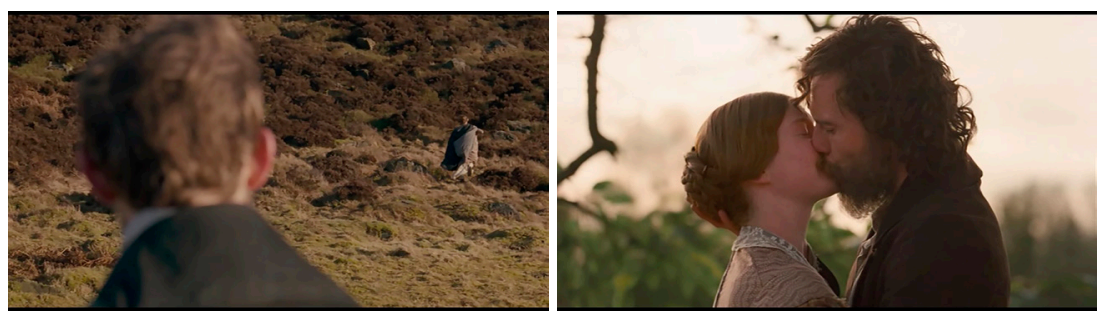

Imágenes 85 y 86. [Fuente: captura de pantalla]. 


\section{Conclusiones}

Hemos desplegado un análisis textual de esta adaptación cinematográfica con el fin de sacar a relucir el carácter subversivo tanto de la clásica novela de Charlotte Brontë como del filme que Moira Buffini y Cary Fukunaga recuperan "para las nuevas generaciones" de mujeres, tal y como leemos en el cartel de la película.

Ambos relatos narran la historia romántica entre Jane - una joven que encarna el conflicto entre la violencia de la pasión sexual femenina y los ideales culturales de pureza y perfección que se descubren mortíferos- $-\mathrm{y}$ Rochester, un hombre apuesto, viril y sexualmente experimentado, que, a diferencia de John Rivers, es capaz de introducir a nuestra joven protagonista en los misterios de la carne.

En un momento histórico-político como el nuestro, que está recuperando los ideales culturales de la pureza femenina - al establecer masivamente las equivalencias discursivas 'hombre=violento'/'mujer=víctima inocente'-, consideramos que el carácter subversivo de este filme radica en dos cuestiones interrelacionadas: por un lado, en que su discurso gira en gran medida en torno a la violencia que nos habita a las mujeres; y, por otro lado, en que su discurso va en dirección contraria al discurso de la 'política correcta' imperante, una política que, a nuestro juicio, apunta a reprimir el deseo irrefrenable, ferozmente apasionado, que puede circular entre un hombre y una mujer.

\section{Bibliografía}

Amorós, Celia (ed.) (2000). Feminismo y filosofía. Madrid: Síntesis.

Apuleyo. (2013). El Asno de Oro. Madrid: Alianza Editorial.

Barthes, Roland. (2001). S/Z. Buenos Aires: Siglo XXI.

Bettelheim, Bruno. (1977). Psicoanálisis del cuento de hadas. Barcelona: Crítica.

Brontë, Charlotte. (1847). Jane Eyre. Barcelona: Alba.

Butler, Judith. (1999). Gender Trouble. Feminism and the subversion of identity. New York and London: Routledge.

Byron, Lord. (1812). Las peregrinaciones de Childe Harold. Madrid: Promociones y Ediciones.

Cecil, David. (1934). Early Victorian Novelists. Londres: Constable.

Craik, Wendy. A. (1968). The Brontë Novels. Londres: Methuen.

Fernández Nistal, Purificación. (1986). Charlotte Brontë y la tradición puritana. Valladolid: Secretariado de Publicaciones de la Universidad de Valladolid.

Freud, Sigmund. (1938 [1940]). "Compendio del psicoanálisis". En Sigmund Freud. Obras Completas, vol. IX. Madrid: Biblioteca Nueva, pp. 3379-3418.

García-Doncel, María R. (1988). El modelo femenino en Jane Eyre. Cádiz: Servicio de Publicaciones de la Universidad de Cádiz.

Gilbert, Sandra y Gubar, Susan. (1979). La loca del desván. La escritora y la imaginación literaria del siglo XIX. Madrid: Cátedra.

González Requena, Jesús. (1995). "Frente al texto fílmico: el análisis, la lectura. A propósito de El manantial, de King Vidor (The Fountainhead, 1949)". En Jesús González Requena (ed.), El análisis cinematográfico. Modelos teóricos, metodologías, ejercicios de análisis. Madrid: Editorial Complutense, pp. 11-46.

Kristeva, Julia. (2000). El porvenir de una revuelta. Barcelona: Seix Barral. 
Krutnik, Frank. (1991). In a Lonely Street: Film Noir, Genre, Masculinity. London and New York: Routledge.

Lacan, Jacques. (1962-1963). El Seminario 10: La angustia. Buenos Aires: Paidós.

Neale, Steve. (1990). “Questions of genre”, Screen, volumen 31, Issue 1, pp. 45-66.

Perojo Arronte, Ma Eugenia. (1994). "Expresión romántica y moralidad en Jane Eyre", Estudios Ingleses de la Universidad Complutense, núm. 2, pp. 263-273.

Rodríguez Magda, Rosa María. (1994). "Feminismo de la igualdad / Feminismo de la diferencia. Algunas acotaciones”. En, Rosa María Rodríguez Magda, Femenino fin de siglo. La seducción de la diferencia. Barcelona: Ed. Anthropos, pp. 37-47.

Talens, Jenaro. (2007). Políticas y laberintos del imaginario. Drácula como síntoma. En Javier Marzal y Francisco Javier Gómez Tarín (ed.), Metodologías de análisis del film. Madrid: Universidad Complutense, pp. 281-297.

Weber, Max. (1905). La ética protestante y el espíritu del capitalismo. Madrid: Alianza.

Woolf, Virginia. (1929). Una habitación propia. Barcelona: Seix Barral.

Woolf, Virginia. (1992). "Professions for Women". En Virginia Woolf, Killing the angel in the house. Nueva York: Penguin Group, pp. 1-9.

Wright, Joseph. (1898-1905). The English Dialect Grammar. Oxford: University Press.

Zupančič, Alenka. (2010). Ética de lo real. Kant, Lacan. Buenos Aires: Prometeo. 